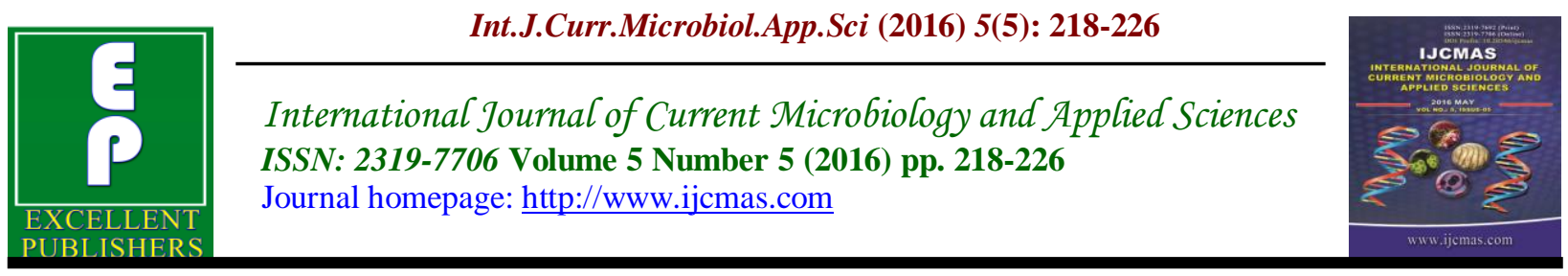

Original Research Article

http://dx.doi.org/10.20546/ijcmas.2016.505.024

\title{
Biochemical and Molecular Characterization of Efficient Phytase Producing Bacterial Isolates from Soil Samples
}

\author{
Sona S. Dev*, Nisha E.A. and Akhil Venu \\ Department of Biotechnology, St Peter's College, Kochi, India \\ *Corresponding author
}

\author{
A B S T R A C T
}

Keywords

Phytase,

Phytic acid,

PSM,

16SrRNA

Lysinibacillus sp.

\section{Article Info}

Accepted:

12 March 2016

Available Online:

10 April 2016
Phytase unavailability in monogastric livestocks leads to the release of undigested phytate phosphorus in their faeces and urine causing severe ecological problems. Phytic acid (or phytate) also acts as an anti-nutritional chelating agent for various metal ions, thus reducing the nutritive quality of food. Hence phytase supplementation can be used to reduce the environmental problem as well as improve the bioavailability of various minerals in food. In the present study efforts were made to isolate, screen and characterize efficient phytase producing strains of bacteria from different soil samples in Central Kerala, India. A total of 42 bacterial isolates were recovered and tested for their phytase activity and three of them, S13 (1), S13 (4) and S14 showed significant phytase activity on Phytase Screening Medium (PSM) agar plate. The isolates were initially identified by morphological and biochemical analysis. Amplification of 16SrRNA gene using specific primers, nucleotide homology analysis and phenotypic characterization revealed that these isolates showed homology to Bacillus sp, Pseudomonas sp. and Lysinibacillus $s p$. respectively. Optimization of culture conditions for maximum phytase production was also carried out. This is the first study that reports the production of phytase from Lysinibacillus sp. isolated from soil samples.

\section{Introduction}

Phytate, an anhydrous salt form of phosphate and phytic acid accounts for more than $80 \%$ of the total phosphorus in cereals and legumes. Phytic acid is also a storage form of myo-inositol - an important growth factor. Under normal physiological conditions phytic acid chelates essential minerals such as calcium, magnesium, iron and zinc. Phytic acid also binds to amino acids and proteins and inhibits digestive enzymes. Thus, phytic acid is an antinutritive component in plant-derived food and feed. Hence, enzymatic hydrolysis of phytic acid is desirable. Phytases ((EC 3.1.3.8 myo-inositol hexakisphosphate phosphohydrolases) are a special class of enzyme that are capable of hydrolyzing phytic acid to less phosphorylated myoinositol derivatives, releasing inorganic phosphate.

Phytase is widespread in nature, occurring in microorganisms, plants, as well as in some animal tissues. The ruminants digest phytic 
acid through the action of phytases produced by the anaerobic gut fungi and bacteria present in their rumenal microflora. However, monogastric animals such as pig, poultry and fish utilize phytate phosphorus poorly because they are deficient in gastrointestinal tract phytases. Therefore, supplemental inorganic phosphate is added to their feed. However it does not diminish the antinutritive effect of phytic acid. This problem can be overcome by hydrolysis of phytate using supplemental phytase which can diminish the antinutritive effects of phytic acid. It is an environmentally friendly product and reduces the cost of diets by removing or reducing the need for supplemental inorganic phosphate. Therefore, phytase has become an important industrial enzyme and is the object of extensive research.

Several phytases have been cloned and characterized, such as fungal phytase from Aspergillus ficuum (Ullah and Phillippy, 1988), bacterial phytase from Escherichia coli (Greiner et al., 1993) and a mammalian phytase (Craxton et al., 1997). These enzymes share a highly conserved sequence motif that is found at the active sites of acid phosphatases (Ullah et al., 1991; Ullah and Dischinger, 1992). The reaction mechanism of E. coli phytase has been revealed (Ostanin et al., 1992; Ostanin and van Etten, 1993) and is likely to be common for most phytases. Therefore, these enzymes are said to form the phytase subfamily of histidine acid phosphatases (Michell et al., 1997).

This study aims to isolate and characterize efficient phytase producing bacterial strains from diverse soil samples collected from pulse fields and poultry farms of Central Kerala. With the advent of PCR, it has become possible to amplify specific genes in the bacterial isolates, offering the possibility for rapid diagnosis and molecular characterization of specific strains of bacteria. Although there are reports of isolation of phytase from various sources, more research needs to be carried out to identify potential microbial strains with greater phytate degrading potential.

\section{Materials and Methods}

\section{Sample Collection}

Soil samples were collected from 43 different sites which includes pulse fields of Muvattupuzha and poultry farms of Valapad and Paravur, Central Kerala, India. They were transported in sterile bags or bottles to the Microbiology Laboratory of St.Peter's College, Kolenchery, Kerala, India for further studies.

\section{Isolation of Bacteria from Samples}

Three replicate samples were randomly collected from three sites of a single location (1m apart) to make a composite sample and this was used for bacterial screening. One gram of each sample was suspended in 10 $\mathrm{ml}$ of sterile distilled water. Serially diluted each sample to $10^{-3}$ and $10^{-4}$ dilutions and spread on nutrient agar medium and incubated for one day.

\section{Screening for Best Phytase Producing Isolate}

The plate screening was carried out for 43 isolates from nutrient agar medium. The colonies on nutrient agar were isolated individually on phytase screening medium (PSM) containing $1.5 \%$ glucose, $0.5 \%$ $\left(\mathrm{NH}_{4}\right)_{2} \mathrm{SO}_{4}, \quad 0.05 \% \quad \mathrm{KCl}, \quad 0.01 \%$ $\mathrm{MgSO}_{4} .7 \mathrm{H}_{2} \mathrm{O}, \quad 0.01 \% \quad \mathrm{NaCl}, \quad 0.01 \%$ $\mathrm{CaCl}_{2} .2 \mathrm{H}_{2} \mathrm{O}, 0.001 \% \mathrm{FeSO}_{4} .7 \mathrm{H}_{2} 0,0.001 \%$ $\mathrm{MnSO}_{4} \cdot \mathrm{H}_{2} \mathrm{O}, \mathrm{pH} 6.5$ with $0.5 \%$ sodium phytate (Hosseinkhani et al., 2009). Medium was sterilized by autoclaving $\left(15 \mathrm{psi}, 121^{\circ} \mathrm{C}\right.$, 
$20 \mathrm{~min})$. After incubation at $30^{\circ} \mathrm{C}$ for 5 days, zone of clearing around the bacterial growth on PSM agar plates was observed by counterstaining with $2 \%$ cobalt chloride, $0.81 \%$ ammonium monovanadate and $12.5 \%$ ammonium molybdate. The zone of clearing around the bacterial growth is an indicator of phytase production. The samples which showed clear zone were considered as positive samples.

\section{Identification of Selected Isolates}

\section{Morphological and Biochemical Tests}

The three most promising phytase-producing isolates (S 13(1), S13 (4) and S 14) were subjected to morphological, physiological, and various biochemical tests following standard methods. Identification of the strains was primarily based on the phenotypic characters described in the Bergey's Manual of Systematic Bacteriology (Holt et al., 2000).

\section{ABIS Online Identification (www.tgw1916.net/bacterialogare desktop.html)}

The results obtained by morphological identification and biochemical tests were fed to ABIS online tool for bacterial identification.

\section{Molecular Identification and Sequencing of Samples}

Genomic DNA was isolated (Janarthanan and Vincent, 2007) and PCR amplification was carried out using 16rDNA universal primers (Forward primer: 5'AACGGCTCA CCAAGGCGACG3'; Reverse primer: 5'GTACCGTCAAGGTGCCGCCC-3') in an Eppendorf Thermocycler.

Automated sequencing of the positive samples was performed at SciGenom Labs Pvt Ltd, Kochi, India.

\section{Construction of Phylogenetic Tree}

Sequenced data were edited using BioEdit Sequence Alignment Editor (Version 7.2.0), aligned and analyzed for finding the closest homolog using National Centre for Biotechnology Information (NCBI) GenBank database. Sequences were deposited to the NCBI GenBank and accession numbers were obtained. Phylogenetic tree was constructed incorporating $16 \mathrm{~S}$ rRNA partial gene sequences of the closest type bacterial strains using MEGA 6.06 (6140226) software following the Maximum Likelihood Method with bootstrap analysis to obtain information on their molecular phylogeny.

\section{Determination of Phytase Enzyme Activity}

Crude culture filtrate was used for estimating the phytase activity by Ammonium molybdate method (Quan et al. 2001). A standard curve was plotted with potassium dihydrogen phosphate (0-100 $\mu \mathrm{g} / \mathrm{mL})$. Heat killed enzyme with the substrate served as control. Each measurement was performed in triplicates. One unit of phytase activity was defined asthe amount of enzyme required to liberate one micromole inorganic phosphate per min under the given assay conditions

\section{Optimization Studies}

The optimum conditions for the isolated phytase producing strains were standardized using PSM as sterile production medium (Choi et al., 2001).

\section{Effect of pH on Phytase Production}

The sterile production medium $(250 \mathrm{~mL})$ with $5 \%$ inoculum was incubated at different $\mathrm{pH}$ such as 4.5, 5.5, 6.5, 7.5 and 8.5 using 
$0.1 \mathrm{~N} \mathrm{NaOH}$ and $0.1 \mathrm{~N} \mathrm{HCl}$ for $120 \mathrm{~h}$ at 200 rpm. The enzyme activity was estimated.

\section{Effect of Temperature on Phytase Production}

The temperature dependence on phytase activity of the three isolated strains was determined in $0.25 \mathrm{M}$ Sodium acetate buffer $\mathrm{pH} 4.5$, in the range $30-50^{\circ} \mathrm{C}$ at every $5^{\circ} \mathrm{C}$.

\section{Results and Discussion}

In this present investigation, out of the 43 bacterial isolates, three species showed efficient phytase activity.

\section{Screening for Phytate Degrading Bacteria}

The zone of clearing around the bacterial growth on PSM agar plates that was observed after 5 days is an indicator of phytase production. The three samples which showed clear zone by counter staining are shown in Figure 1.

\section{Morphological and Biochemical Test Results of Bacterial Isolates}

Morphological characteristics obtained for the 3 isolated samples are indicated in Table 1 .

The biochemical test result obtained for the three isolated samples are indicated in Table 2 .

\section{ABIS online Identification of the Cultures}

The ABIS online bacterial identification of the isolated strains S13(1),S13(4) and S14 indicates that the $\mathrm{S} 13(1)$ isolate may be Bacillus smithii, S13(4) isolate shows $88 \%$ similarity towards Pseudomonas pertucinogena, Moraxirlla bovis, Moraxiella bovoculi and Moraxiella cuniculi and the isolate S14 showed $80 \%$ similarity towards Bacillus coagulans, Paenibacillus curdianolyticus and Paenibacillus validius respectively.

\section{Molecular Identification and Sequencing of Samples}

Amplification of DNA isolated from three pure cultures of S13 (1), S13 (4) and S14 with RW01 and DG74 primers specific for 16srDNA, generated amplicons of $370 \mathrm{bp}$ respectively (Figure 2). The sequenced amplicons of the three isolates were then submitted to NCBI GenBank database and assigned Accession Numbers KU997688, KU997689, KU997690, respectively.

\section{Phylogenetic Analysis}

Nucleotide homology of the $16 \mathrm{~S}$ rRNA partial gene sequences was inferred by

BLAST search in the NCBI GenBank database. The analysis involving 9 BLAST sequences of similar homologs which were found in GenBank revealed that the three samples S13 (1), S13 (4) and S14 have 98\% sequence similarity with Bacillus anthracis (GenBank Accession no. KT184959.1, E value $6 \mathrm{e}-62), 100 \%$ sequence similarity with Pseudomonas sp. (GenBank Accession no. KP671493.1, E value -2e-97) and 100\% sequence similarity with Lynsinibacillus (GenBank Accession no.JF693981.1, E value - 2e-97) respectively. Phylogenetic relation of the three identified bacterial isolates with other closely related type strains retrieved from the NCBI database are presented in the dendrograms (Figure 3, Figure 4, Figure 5).

\section{Optimization of Culture Condition}

\section{Effect of pH on Phytase Production}

Maximum phytase production was obtained at $\mathrm{pH} 6.5$ for S-14(14.22 IU/L) and S 13(1) (13.11 IU/L). However S-13(4) (13.11 IU/L) 
showed maximum phytase production at $\mathrm{pH}$ 7as shown in Figure 6. Effect of Temperature on Phytase
Production

Temperature is one of the most critical parameters to be controlled in any bioprocess. The effect of temperature on phytase production revealed that maximum yield was obtained at $40^{\circ} \mathrm{C}$ for S-14 (14.22 IU/L), S-13(1) (13.11 IU/L) and S-134) (12.88 IU/L) as shown in Figure 7.

Table.1 Morphological characteristics of S13 (1) and S13 (4) and S14 samples

\begin{tabular}{|l|l|l|l|}
\hline Morphology & S13(1) & S13(4) & S14 \\
\hline $\begin{array}{l}\text { 1.Size of } \\
\text { colony }\end{array}$ & Small & Small & Small \\
\hline 2.Margin & Entire & Entire & Entire \\
\hline 3.Elevation & Flat & Raised & Flat \\
\hline 4.Pigmentation & Creamy growth & Creamy growth & Non pigmented \\
\hline $\begin{array}{l}\text { 5.Gram } \\
\text { Staining }\end{array}$ & $\begin{array}{l}\text { Gram positive rods (purple } \\
\text { coloured) }\end{array}$ & $\begin{array}{l}\text { Gram negative rods (pink } \\
\text { coloured) }\end{array}$ & $\begin{array}{l}\text { Gram positive rods } \\
\text { (purple coloured) }\end{array}$ \\
\hline
\end{tabular}

Table.2 Biochemical test results of S13 (1), S13 (4) and S14 samples

\begin{tabular}{|c|c|c|c|c|c|c|c|c|c|c|c|}
\hline Sample & $\begin{array}{l}\text { Indol } \\
\text { e test }\end{array}$ & $\begin{array}{l}\text { MR } \\
\text { test }\end{array}$ & $\begin{array}{l}\text { VP } \\
\text { test }\end{array}$ & $\begin{array}{l}\text { Citrate } \\
\text { test }\end{array}$ & $\begin{array}{l}\text { Ureas } \\
\text { e test }\end{array}$ & $\begin{array}{l}\text { Lactose } \\
\text { fermentati } \\
\text { on test }\end{array}$ & $\begin{array}{l}\text { Sucrose } \\
\text { fermentatio } \\
n \text { test }\end{array}$ & $\begin{array}{l}\text { Dextrose } \\
\text { fermentat } \\
\text { ion test }\end{array}$ & $\begin{array}{l}\text { Starch } \\
\text { hydrolys } \\
\text { is test }\end{array}$ & $\begin{array}{l}\text { Catalase } \\
\text { test }\end{array}$ & $\begin{array}{l}\text { Oxidase } \\
\text { Test }\end{array}$ \\
\hline S13(1) & -ve & $+\mathrm{ve}$ & -ve & -ve & $+\mathrm{ve}$ & -ve & -ve & -ve & $+\mathrm{ve}$ & $+\mathrm{ve}$ & $+\mathrm{ve}$ \\
\hline S13(4) & -ve & -ve & -ve & -ve & -ve & -ve & -ve & -ve & $+\mathrm{ve}$ & $+\mathrm{ve}$ & -ve \\
\hline S14 & -ve & $+\mathrm{ve}$ & -ve & -ve & $+\mathrm{ve}$ & -ve & -ve & -ve & $+\mathrm{ve}$ & $+\mathrm{ve}$ & $+\mathrm{ve}$ \\
\hline
\end{tabular}

Figure.1 Halo formation on PSM of S13 (1), S13 (4) and S14 samples
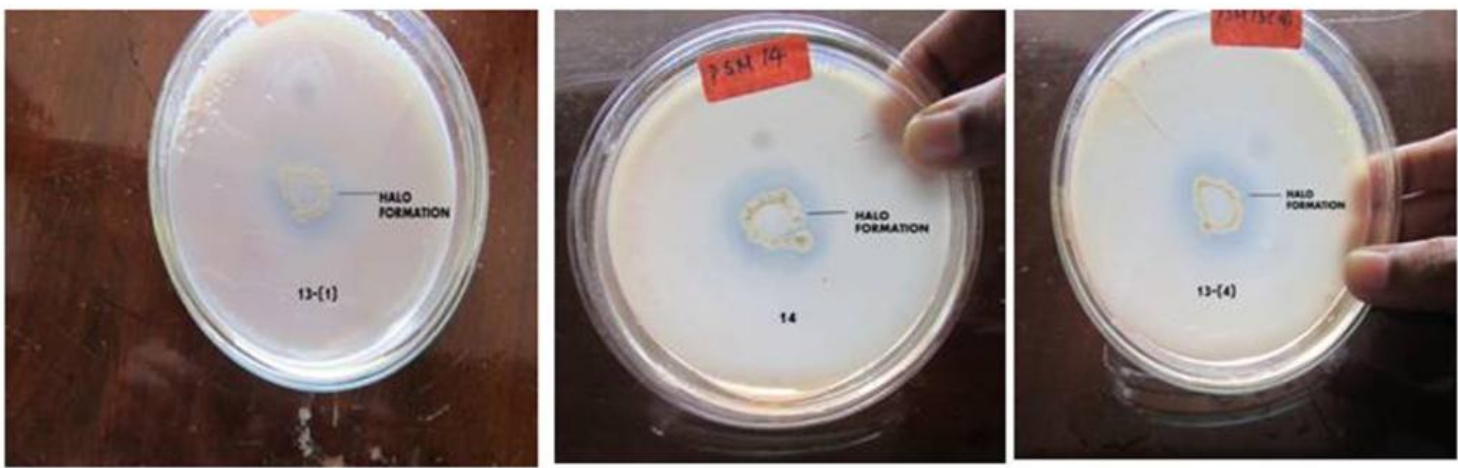
Figure.2 Confirmation of samples S13 (1), S13 (4) and S14 by PCR using 16s rDNA specific primers

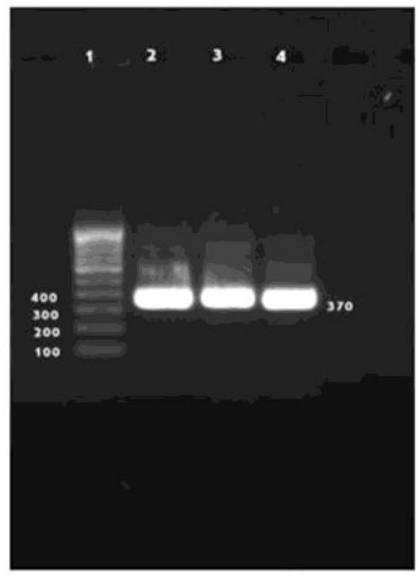

Figure.3 Dendrogram showing phylogenetic relations of the bacterial strain S_13(1) with other closely related bacterial strains retrieved from NCBI GenBank. Similarity and homology of the neighbouring sequences have been shown by the bootstrap values.

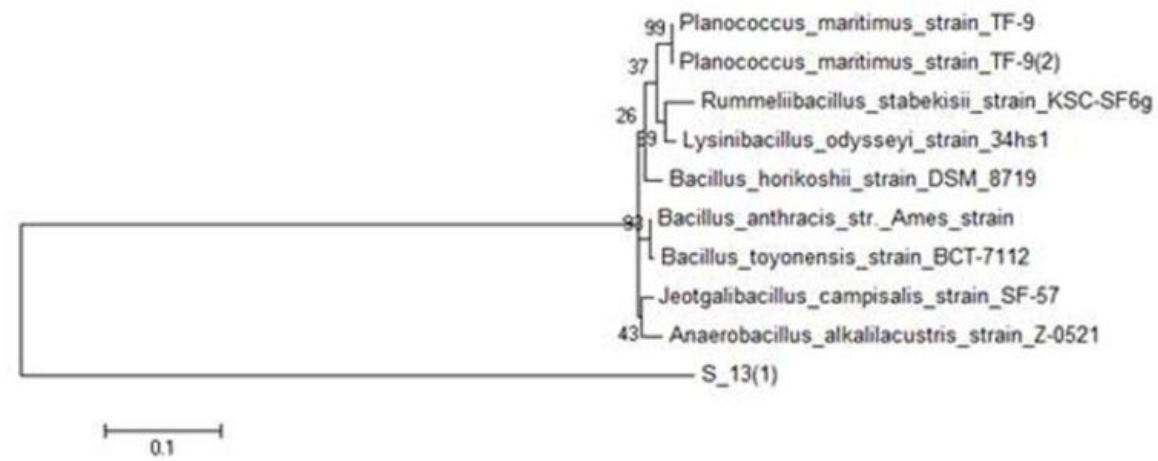

Figure.4 Dendrogram showing phylogenetic relations of the bacterial strain S_13_(4) with other closely related bacterial strains retrieved from NCBI GenBank. Similarity and homology of the neighbouring sequences have been shown by the bootstrap values.

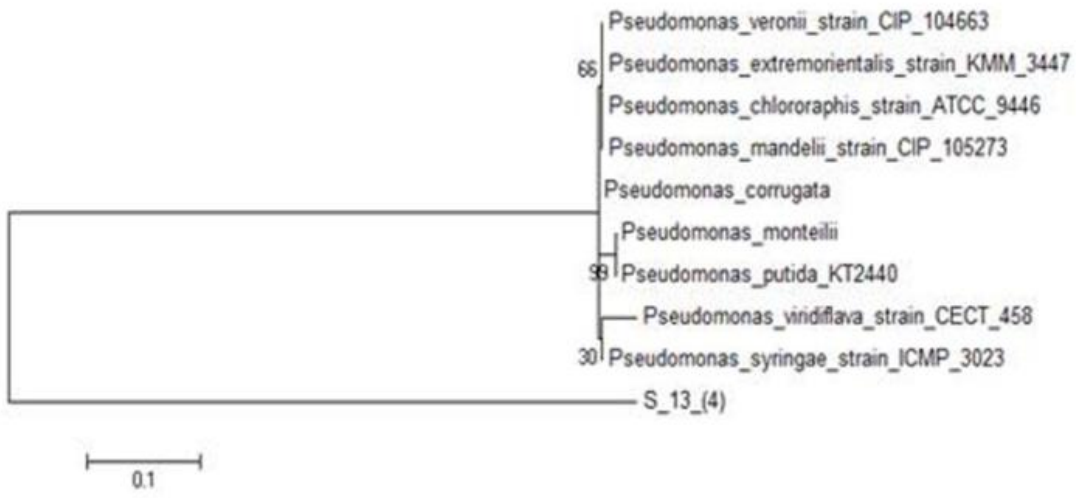


Figure.5 Dendrogram showing phylogenetic relations of the bacterial strain S_14(1) with other closely related bacterial strains retrieved from NCBI GenBank. Similarity and homology of the neighbouring sequences have been shown by the bootstrap values.

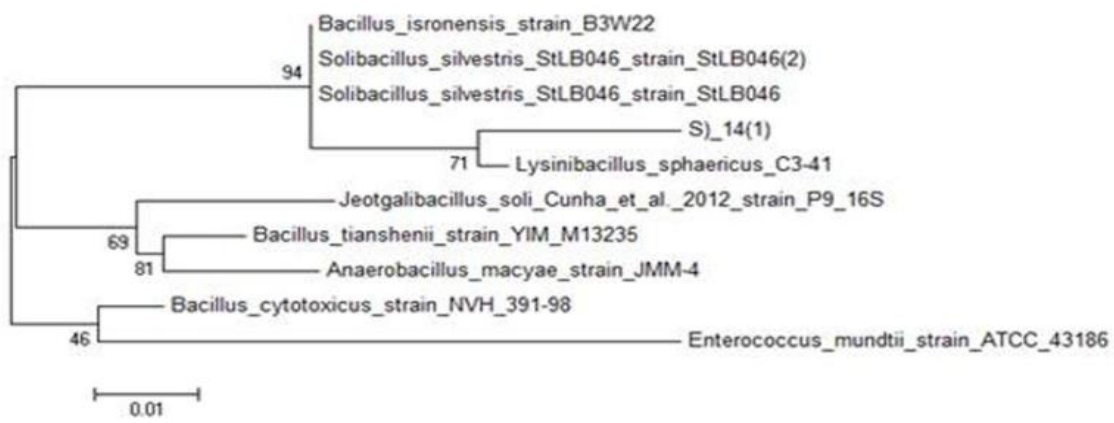

Figure.6 Effect of $\mathrm{pH}$ on phytase production

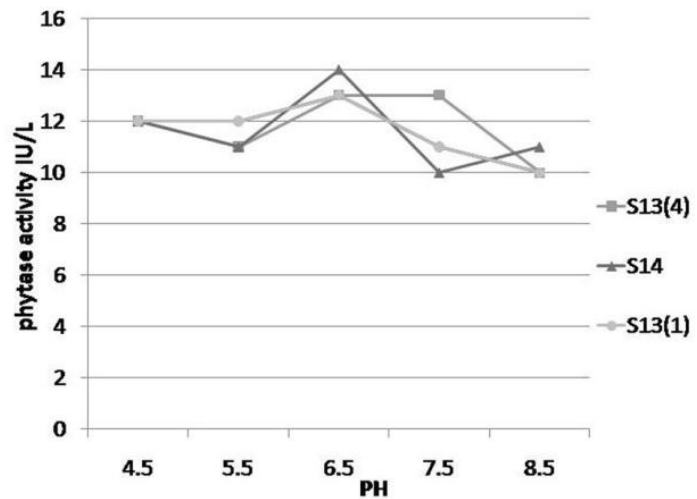

Figure.7 Effect of temperature on phytase production

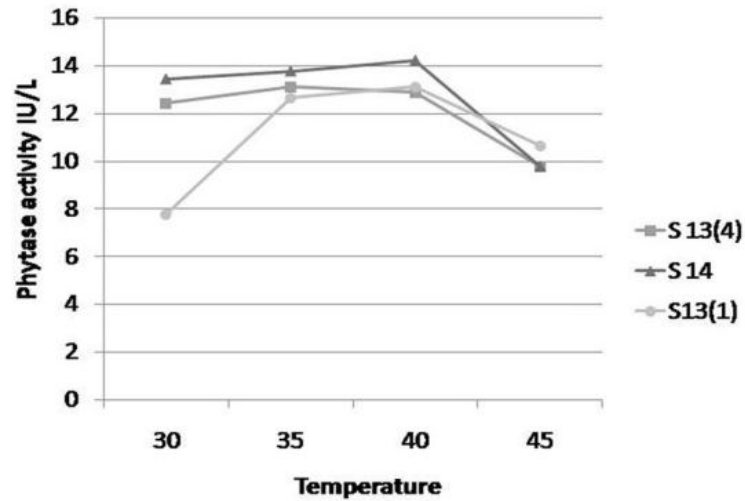


Naturally microorganisms are having ability to produce variety of industrial enzymes like amylase, protease, cellulase, lipase, pectinase, phosphatase, etc., and most of the enzymes are industrially important for human welfare (Ponmurugan and Gopi, 2006). In higher plants phytases occur predominantly in grains, seeds and pollen (Konietzny and Greiner, 2002), where they are responsible for phytate degradation during germination to make phosphate, minerals and myo-inositol available for plant growth. In this present investigation, among the phytase bacterial species that were isolated, Lysinibacillus strain isolated produced maximum phytase activity when incubated at $40^{\circ} \mathrm{C}$. The temperature requirement of the organism is based on the nature of environment where they are grown. The $\mathrm{pH}$ is the another important parameter which determines the growth of the organism and phytase production. The Bacillus megaterium isolated from coastal region has produced the extra cellular phytase at $\mathrm{pH} 9$ (Dhiraj et al., 2013) but Bacillus anthracis isolated from the soil sample has shown higher production at $\mathrm{pH}$ 6.5. The genus of Pseudomonas sp. isolated from poultry sample has produced the extra cellular phytase at $\mathrm{pH} 6$ and optimum temperature was found to be $37^{\circ} \mathrm{C}$ (Sasirekha et al., 1990), but the Pseudomonas sp. isolated from the soil sample has shown higher production at $\mathrm{pH}$ 6.5 and optimum temperature was found to be $40^{\circ} \mathrm{C}$. The carbohydrates are essential energy source for most of heterotrophic organisms. The nitrogen sources are of secondary energy sources for the organisms, which play an important role in the growth of the organism and their production.

In conclusion, the present study we have isolated three efficient phytase producing bacteria from soil sample from pulse fields of Central Kerala, India. The ability of soil microorganisms to solubilize various forms of precipitated phosphorus has already been well documented by various researchers. More research to identify microbial strains with greater phytate degrading potential recorded as on date, need to be carried out. Among the isolated enzymes, the higher phytase production by Lysinibacillus strain can be further exploited to be used as feed supplement in animal diet and also for reduction of phosphorus pollution in areas of livestock production. The phytate-degrading property of this enzyme can also be used in many applications especially in food industries. Further studies are to be carried out to scale up the production and purify the isolated enzyme.

\section{Acknowledgment}

We wish to thank the Kerala State Council for Science Technology and Environment, Kerala India, for the research funding.

\section{References}

Choi, Y.M, Suh, H.J., Kim, J.M. 2001. Purification and properties of extracellular phytase from Bacillus spKHU-10. J. Protein Chem., 20: 287-292.

Craxton, A., Caffrey, J.J., Burkhart, W., Safrany, S.T., Shears, S.B. 1997. Molecular cloning and expression of a rat hepatic multiple inositol polyphosphate phosphatase. Biochem. J., 328: 75-81.

Greiner, R., Konietzy, U., Jany, K.D. 1993. Purification and characterization of two phytases from Escherichia coli. Arch. Biochem. Biophys., 303: 107113.

Holt, J.G., Krieg, N.R., Sneathm, P.H.A., Staley, J.T., Williams, S.T. 1994. In: Bergey's Manual of Determinative Bacteriology, 9th edn.Baltimore, 
MD: Williams and Williams.

Hosseinkhani, B., Emtiazzi, G., Nahvi, I. 2009. Analysis of phytase producing bacteria (Pseudomonas sp.) from poultry faeces and optimization of this enzyme production. Afr. J. Biotechnol., 8: 4229-4232.

Janarthanan, S., Vincent, S. 2007. Phenol chloroform extraction of DNA. In: Practical Biotechnology. Pp.29-30.

Konietzny, U., Greiner, R. 2003. Phytic acid: nutritional impact. In: Encyclopedia of Food Science and Nutrition, B. Caballero, L. Trugo, P. Finglas Eds., Elsevier, London, UK. Pp. 4555-4563.

Kumar, D., Rajesh, S., Balashanmugam, P., Rebecca, L.J., Kalaichelvan, P.T. 2013. Screening, optimization and applications of extracellular phytase from Bacillus megaterium isolated from poultry waste. J. Mod. Biotechnol., 2: 46-52.

Michell, D.B., Vogel, K., Weimann, B.J., Pasamontes, L.,van Loon. 1997. The phytase subfamily of histidine acid phosphatases: isolation of two genes for two novel phytases from the fungi Aspergillusterrus and Myceoliophthora thermophile. Microbiol., 143: 245-252.

Ostanin, K., van Etten, R.L. 1993. Asp304 of Escherichia coli acid phosphatase is involved in leaving group protonation. J. Biol. Chem., 268: 20778-20784.

Ostanin, K., Harms, E.H., Stevis, P.E., Kuciel, R., Zhou, M., Van Etten,
R.L. 1992. Overexpression, sitedirected mutagenesis, and mechanism of Escherichia coli acid phosphatase. J. Biol. Chem., 267: 22830-22836.

Ponmurugan, P., Gopi, C. 2006. In vitro production of growth regulators and phosphatase activity by phosphate solubilizing bacteria. Afri. J. Biotechnol., 5: 348-350.

Quan, C., Zhang, L., Wang, Y., Ohta, Y. 2001. Production of phytase in low phosphate medium by a novel yeast Candida krusei. J. Biosci. Bioengi., 92: 154-160.

Sasirekha, B., Bedashree, T., Champa, K.L. 1990. Optimization and partial purification of extracellular phytase from Pseudomonas aeruginosa p6 European J. Experimental Biol., 2(1): 95-104.

Ullah, A.H.J., Dischinger. 1992. Aspergillus ficuum phytase: Complete primary structure elucidation by chemical sequencing. Biochem. Biophys., 192: 747-753.

Ullah, A.H.J., Phillippy, B.Q. 1988. Immobilization of Aspergillus ficuum phytase: product characterization of the reactor, Prep. Biochem., 18: 483-489.

Ullah, A.H.J., Barry, J., Cummins, Charles, H., Dischinger. 1991. Cyclohexanedione modification of arginine at the active site of Aspergillus ficuum phytase. Biochem. Biophys. Res. Commu., 178: 45-53.

\section{How to cite this article:}

Sona S. Dev, Nisha E.A. and Akhil Venu. 2016. Biochemical and Molecular Characterization of Efficient Phytase Producing Bacterial Isolates from Soil Samples. Int.J.Curr.Microbiol.App.Sci. 5(5): 218-226. doi: http://dx.doi.org/10.20546/ijcmas.2016.505.024 